\title{
Induced resistance and associated defence gene responses in Pinus patula
}

\author{
Katrin Fitza ${ }^{1 *}$, AA Myburg${ }^{1}$, Emma Steenkamp², Kitt Payn ${ }^{3}$, Sanushka Naidoo \\ From IUFRO Tree Biotechnology Conference 2011: From Genomes to Integration and Delivery \\ Arraial d'Ajuda, Bahia, Brazil. 26 June - 2 July 2011
}

\section{Background}

Plants are able to incite a type of broad spectrum resistance against pathogens upon pre-treatment with biological or chemical inducers. Systemic Acquired Resistance (SAR) and Induced Systemic Resistance (ISR) are two types of induced resistance which lead to the accumulation of specific pathogenesis-related (PR) proteins. Non-pathogenic rhizobacteria are inducing agents for ISR and increased levels of ethylene (ET) and jasmonate (JA) are associated with this pathway, whereas SAR is associated with an increase in salicylic acid (SA) levels [1].

Pinus patula and $P$. radiata are commercially planted conifer species in South Africa, but are both highly susceptible to the causal agent of pitch canker, Fusarium circinatum. Annually, the forestry sector suffers substantial economic losses due to this disease which affects $20-30 \%$ of the planting stock. Bonello et al. (2001) showed that repeated mechanical inoculation of $P$. radiata with $F$. circinatum activated induced resistance, enhancing the protection of the tree against subsequent pathogen challenge [2].

Detailed knowledge of the molecular mechanisms underlying induced resistance may be useful to develop strategies to control diseases of pine trees. This study aimed to compare the efficiency of ten biological and chemical inducers in inciting resistance against $F$. circinatum. Additionally the molecular basis of this induced resistance was investigated by analyzing the response of selected putative defence response genes.

\section{Methods}

Ten activators of induced resistance $\left(\right.$ Bion $^{\circledR}$, Messenger $^{\circledR}$, Chitin, MeJA, Fusarium oxysporum, Pseudomonas

\footnotetext{
* Correspondence: katrin.fitza@fabi.up.ac.za

'Department of Genetics, University of Pretoria, Pretoria 0002, South Africa Full list of author information is available at the end of the article
}

fluorescens, SA, Kannar, Ralstonia solanacearum and potassium phosphate monobasic) were compared. A set of 80 P. patula seedlings were used per treatment. Inducers were applied at four and six months of age and F. circinatum spores $\left(1 \times 10^{4}\right)$ were used to challenge the seedlings a week after the booster application (six months). Disease severity was assessed six weeks after inoculation by comparing the size of the lesions on treated plants to water control plants. Three inducers that curbed symptoms most successfully were selected for further analysis. A set of 116 plants per treatment were screened weekly for eight weeks. Aerial parts of the six month old plants were harvested for RNA isolation at $24 \mathrm{hrs}$ after the second application. For each treatment, three replicates, with 12 plants per replicate, were harvested. Subsequently, RNA was extracted for the reverse transcriptase quantitative PCR (RT-qPCR) analysis, where four putative defence genes were profiled using the Roche LightCycler ${ }^{\circledR} 480$ instrument.

\section{Results and discussion}

MeJA, Messenger and chitin treatment resulted in the reduction in symptom severity (results not shown). MeJA, Messenger and the deacetylated version of chitin, chitosan were then tested under stringent inoculation conditions with $F$. circinatum to verify the effectiveness of the inducers. The most promising treatment was chitosan at a concentration of $10 \mathrm{mg} / \mathrm{ml}$, which resulted in a significant reduction in lesion length over a period of 6 weeks. Lesion lengths were converted to percentage live stem (calculated as lesion length divided by plant height multiplied by 100) and are displayed in Table 1.

The defence response elicited by chitosan application was investigated. Four putative genes, representing the onset of SAR and ISR were analyzed (Table 2). Phenylalanine ammonia lyase $(P A L)$ had a three-fold accumulation in transcript expression in comparison to uninduced 
Table 1 Disease progression represented as percentage live stem in 6 month old $P$. patula seedlings during an eight week period post inoculation with $F$. circinatum. The significance levels are relative to the relevant control.

\begin{tabular}{lccccccc}
\hline Week & $\mathbf{2}$ & $\mathbf{3}$ & $\mathbf{4}$ & $\mathbf{5}$ & $\mathbf{6}$ & $\mathbf{7}$ & $\mathbf{8}$ \\
\hline $\begin{array}{l}\text { Chitosan } \\
(\mathbf{1 m g} / \mathbf{m l})\end{array}$ & 89.73 & 82.31 & 76.75 & 71.43 & 60.81 & 61.16 & 36.10 \\
$\begin{array}{l}\text { Chitosan } \\
(\mathbf{1 0 m g} / \mathbf{m l})\end{array}$ & $91.12^{*}$ & $84.89^{*}$ & $80.60^{*}$ & $72.80^{*}$ & $64.28^{*}$ & 60.32 & 44.18 \\
$\quad$ Control & 89.23 & 82.10 & 74.48 & 69.04 & 58.65 & 55.15 & 34.53 \\
\hline${ }^{*} \mathrm{p}<0.05$, Kruskal-Wallis test. & & & & & &
\end{tabular}

plants (Table 2). The expression level of the 1-deoxy-dxylulose-5-phosphate synthase $(D X S)$ gene, which catalyses the methyl erythriol-phosphate pathway, was down-regulated in comparison to the control. This pathway is important for the production of terpenes, which are building blocks for resin [3]. In previous studies, $P A L$ and $D X S$ were both shown to be responsive to chitosan. Using the $P A L$ gene as a diagnostic marker of the phenylpropanoid pathway, the up-regulation of the transcript suggests that chitosan treatment induces the phenylpropanoid pathway which is known to lead to the production of secondary metabolites to elicit resistance.

\section{Conclusion}

The potential of priming P. patula to defend itself against pathogen attack was explored. We tested the application of ten different inducers to enhance tolerance to $F$. circinatum. The application of chitosan reduced pitch canker symptoms. Reduced lesion length was observed for a period of six weeks, indicating the activation of induced resistance. Further molecular analysis suggests that the treatment may activate the phenylpropanoid pathway, which is involved in the production of secondary metabolites that have antifungal properties [4]. Entire defence response pathways influenced by chitosan application in P. patula will be investigated in subsequent expression profiling assays.

Table 2 Log2 expression levels of putative defence response genes in $P$. patula 24 hrs after booster treatment with $10 \mathrm{mg} / \mathrm{ml}$ chitosan. Three biological replicates were used to calculate significance using the t-test.

\begin{tabular}{llll}
\hline $\begin{array}{l}\text { Gene } \\
\text { symbol }\end{array}$ & Gene Name & $\begin{array}{l}\text { Log2 } \\
\text { Expression }\end{array}$ & $\begin{array}{l}\text { P-value } \\
\text { (t-test) }\end{array}$ \\
\hline PAL & Phenylalanine ammonia lyase & 1.773 & 0.028 \\
DXS & $\begin{array}{l}\text { I-deoxy-d-xylulose-5-phosphate } \\
\text { synthase }\end{array}$ & -1.142 & 0.041 \\
FMO & $\begin{array}{l}\text { Flavin-dependent } \\
\text { monoxygenase }\end{array}$ & 0.486 & 0.173 \\
PR-3 & Chitinase & -0.997 & 0.199 \\
\hline
\end{tabular}

Author details

'Department of Genetics, University of Pretoria, Pretoria 0002, South Africa. ${ }^{2}$ Department of Microbiology, Forestry and Agricultural Biotechnology Institute (FABI), University of Pretoria, Pretoria 0002, South Africa. ${ }^{3}$ Mondi South Africa, P.O. Box 12, Hilton, 3245, South Africa.

Published: 13 September 2011

\section{References}

1. Gurr S, Rushton P: Engineering plants with increased disease resistance. Trends Biotechnol 2005, 23:275-282.

2. Bonello P, Gordon T, Storer A: Systemic induced resistance in Monterey pine. Forest Pathol 2001, 31:99-106.

3. Kim Y, Kim S, Kang M: Regulation of resin acid synthesis in Pinus densiflora by differential transcription of genes encoding multiple 1deoxy-D-xylulose 5-phosphate synthase and 1-hydroxy-2-methyl-2-(E)butenyl 4-diphosphate reductase genes. Tree physiol 2009, 5:1-13.

4. Ferrer J, Austin M, Stewart J: Structure and function of enzymes involved in the biosynthesis of phenylpropanoids. Plant Physiol 2008, 46:356-370.

doi:10.1186/1753-6561-5-S7-P82

Cite this article as: Fitza et al:: Induced resistance and associated defence gene responses in Pinus patula. BMC Proceedings 2011 5(Suppl 7):P82.
Submit your next manuscript to BioMed Central and take full advantage of:

- Convenient online submission

- Thorough peer review

- No space constraints or color figure charges

- Immediate publication on acceptance

- Inclusion in PubMed, CAS, Scopus and Google Scholar

- Research which is freely available for redistribution 